\title{
PENGARUH LDR, IPR, APB, NPL, IRR, BOPO, PR, DAN FACR TERHADAP ROA PADA BANK SWASTA NASIONAL GO PUBLIC
}

\author{
LUTVI ALAMSYAH., SE.,MM., CRMP \\ E-mail lutvitjia5@gmail.com
}

\begin{abstract}
Abstrak
Pada penelitian ini tidak mengabaikan adanya penelitian terdahulu yang sangat bermanfaat sebagai acuan bagi penulis, yaitu penelitian yang dilakukan oleh Mertika Kirana Rimadhani 2010 yang berjudul "pengaruh LDR, IPR, APB, NPL, Assets Utilazation, BOPO, IRR dan PDN terhadap return on asset (ROA) pada bank swasta nasional go public". Permasalahan yang di bahas oleh Mertika Kirana Rimadhani adalah apakah LDR, IPR, APB, NPL, Assets Utilazation, FACR, BOPO dan PDN secara bersama sama ataupun secara parsial mempunyai pengaruh yang signifikan terhadap Return On Asset (ROA) pada bankbank swasta nasional go public periode 2006 sampai dengan 2009. Teknik Pengambilan sampel yang digunakan dalam penelitian ini adalah purposive sampling, yaitu pemilihan berdasarkan pada kriteria tertentu yang mempunyai sangkut-pautnya dengan kriteria populasi yang sudah diketahui sebelumnya yaitu Bank Swasta Nasional Go Public.
\end{abstract}

Kata Kunci : PENGARUH LDR, IPR, APB, NPL, IRR, BOPO, PR, DAN FACR 


\section{PENDAHULUHAN}

Dalam rangka menciptakan industri perbankan kedepan yang lebih sehat, baik dan stabil, keberadaan perbankan saat ini perlu di kaji lagi keberadaanya, dimana dapat di lihat apakah struktur perbankan nasional kita memang sudah sejalan dengan perkembangan saat ini. selain memperhatikan strukutur perbankan yang sehat, maka dalam industri perbankan tersebut juga perlu melihat adanya persaingan antara lembaga-lembaga keuangan yang merupakan unsur lingkungan bisnis perbankan yang harus didasari dan di gunakan sebagai bahan pertimbangan dalam segala pengambilan keputusan dalam dunia perbankan tersebut.

Bank pada dasarnya adalah lembaga perantara keuangan, yaitu mengumpulkan dana dari masyarakat yang kelebihan dana dan kemudian akan disalurkan kembali pada masyarakat yang kekurangan dana dalam bentuk kredit atau yang lainnya dengan tujuan untuk meningkatkan taraf hidup masyarakat luas.

Dalam kegiatannya, bank memiliki tiga tujuan penting yaitu likuiditas yang merupakan pemenuhan kewajiban jangka pendek, solvabilitas yang merupakan kemampuan permodalan bank, dan rentabilitas yang merupakan kemampuan bank tersebut dalam memperoleh laba. Untuk kelangsungan hidup bank, ketiga faktor tersebut harus slalu berjalan seimbang. Sedangkan untuk 
mengukur tingkat kinerja perbankan adalah dengan menggunakan rasio-rasio keuangan. Rasio keuangan tersebut untuk melihat tingkat profitabilitas dari suatu bank dimana rasio tersebut sangat berpengaruh pada suatu perhitungan pendapatan suatu bank. Karena obyek yang digunakan sebagai penelitian adalah bank, maka posisi asset menunjukan suatu kegiatan usaha yang berpengaruh dengan penggunaan dana terutama dalam memperoleh keuntungan (profit).

Salah satu tujuan yang akan selalu diupayakan bank untuk dicapai adalah memperoleh keuntungan. Dengan diperolehnya keuntungan, maka bank akan dapat hidup dan berkembang dari waktu ke waktu. Tingkat kemampuan dalam menghasilkan keuntungan bank dapat diukur dengan rasio keuangan yang salah satu diantaranya adalah ROA. Return On Asset merupakan indikator yang menggambarkan bukan hanya kemampuan manajemen untuk mengendalikan seluruh biaya operasional dan non operasional, serta dapat digunakan untuk mengukur kemampuan bank dalam memperoleh keuntungan secara keseluruhan, sehingga apabila ROA suatu bank besar maka semakin besar pula tingkat keuntungan yang dicapai bank tersebut, sehingga akan semakin baik pula posisi bank tersebut dari segi penggunaan asset. ROA adalah rasio antara laba sebelum pajak dengan rata-rata total asset.

Adapun perkembangan bank-bank umum swasta nasional go public yang ditinjau dari ROA mulai triwulan IVtahun 2007 sampai triwulan III tahun 2011 yang didapatkan dari laporan keuangan publikasi Bank Indonesia. Besarnya ROA yang dimiliki sebuah bank seharusnya meningkat. Namun tidak demikian halnya yang terjadi pada bank yang di tunjukan pada tabel 1.1 
Tabel 1.1

Posisi ROA pada Bank Swasta Nasional Go Public Tahun 2007-2011

\begin{tabular}{|c|c|c|c|c|c|c|c|c|c|c|c|}
\hline \multirow{2}{*}{ NO } & \multirow{2}{*}{ NAMA BANK } & \multicolumn{9}{|c|}{ ROA } & \multirow{2}{*}{ Rata-Rata Trend } \\
\hline & & 2007 & 2.008 & trend & 2009 & trend & $2010^{*}$ & trend & $2011 *$ & trend & \\
\hline 1 & PT BANK CIMB NIAGA, Tbk & 2,2 & 1,1 & $-1,1$ & 2,11 & 1,01 & 2,62 & 0,51 & 2,83 & 0,21 & 0,1575 \\
\hline 2 & PT BANK BUKOPIN TBK & 1,63 & 1,66 & 0,03 & 1,46 & $-0,2$ & 1,53 & 0,07 & 1,66 & 0,13 & 0,0075 \\
\hline 3 & PT BANK CENTRAL ASIA,TBK & 3,34 & 3,42 & 0,08 & 3,4 & $-0,02$ & 3,5 & 0,1 & 3,75 & 0,25 & 0,1025 \\
\hline 4 & PT BANK DANAMON INDONESIA TBK & 3,41 & $\mathbf{1 , 7 8}$ & $-1,63$ & 2,01 & $\mathbf{0 , 2 3}$ & 3,55 & $\mathbf{1 , 5 4}$ & 3,15 & $-0,4$ & $-0,065$ \\
\hline 5 & PT BANK tabungan pensiunan TBK & 6,14 & 4,48 & $-1,66$ & 3,42 & $-1,06$ & 3,9 & 0,48 & 4,43 & $\mathbf{0 , 5 3}$ & $-0,4275$ \\
\hline 6 & PT BANK MEGA TBK & 2,33 & 1,98 & $-0,35$ & 1,77 & $-0,21$ & 2,22 & 0,45 & 1,69 & $-0,53$ & $-0,16$ \\
\hline 7 & PT BANK OCBC NISP TBK & 1,31 & 1,54 & 0,23 & 1,79 & 0,25 & 1,87 & 0,08 & 1,83 & $-0,04$ & 0,13 \\
\hline 8 & PT BANK PERMATA TBK & 1,9 & 1,7 & $-0,2$ & 1,4 & $-0,3$ & 2,28 & 0,88 & 1,91 & $-0,37$ & 0,0025 \\
\hline 9 & PT PAN INDONESIA BANK TBK & 3,14 & $\mathbf{1 , 7 5}$ & $-1,39$ & $\mathbf{1 , 7 8}$ & $\mathbf{0 , 0 3}$ & 2,29 & $\mathbf{0 , 5 1}$ & $\mathbf{1 , 8 2}$ & $-0,47$ & $-\mathbf{- 0 , 3 3}$ \\
\hline 10 & PT BANK victoria international TBK & 1,64 & 0,88 & $-0,76$ & 1,1 & 0,22 & 1,82 & 0,72 & 3,08 & 1,26 & 0,36 \\
\hline 11 & PT BANK INTERNASIONAL INDONESIA TBK & 1,23 & 1,23 & 0 & 0,09 & $-1,14$ & 1,04 & 0,95 & 1,26 & 0,22 & 0,0075 \\
\hline 12 & PT BANK MUTIARA TBK & 0,37 & $-52,09$ & $-52,46$ & 3,84 & 55,93 & 1,13 & $-2,71$ & 3,27 & 2,14 & 0,725 \\
\hline 13 & PT BANK ARTHA GRAHA INTERNASIONAL, TBK & 0,29 & 0,34 & 0,05 & 0,44 & 0,1 & 0,76 & 0,32 & 0,92 & 0,16 & 0,1575 \\
\hline 14 & PT BANK ICBC Bumi putera TBK & 0,57 & 0,45 & $-0,12$ & 0,3 & $-0,15$ & 0,49 & 0,19 & 0,66 & 0,17 & 0,0225 \\
\hline 15 & PT BANK Capital Indonesia TBK & $\mathbf{1 , 9 4}$ & $\mathbf{1 , 1 4}$ & $-0,8$ & $\mathbf{1 , 4 2}$ & $\mathbf{0 , 2 8}$ & $\mathbf{1 , 2 1}$ & $-0,21$ & $\mathbf{1 , 1 4}$ & $-\mathbf{0 , 0 7}$ & $-0,2$ \\
\hline 16 & PT BANK BUMI ARTA TBK & $\mathbf{1 , 6 8}$ & $\mathbf{2 , 0 7}$ & $\mathbf{0 , 3 9}$ & 2 & $-0,07$ & $\mathbf{1 , 4 8}$ & $-0,52$ & 1,6 & $\mathbf{0 , 1 2}$ & $-\mathbf{- 0 , 0 2}$ \\
\hline 17 & PT BANK MAYAPADA INTERNATIONAL, TBK & 1,46 & $\mathbf{1 , 2 7}$ & $-0,19$ & $\mathbf{0 , 9}$ & $-0,37$ & 2,17 & 1,27 & $\mathbf{1 , 2 5}$ & $-0,92$ & $-0,0525$ \\
\hline 18 & PT BANK EKONOMI RAHARJA,TBK & 1,87 & 2,26 & $\mathbf{0 , 3 9}$ & 2,21 & $-0,05$ & 2,1 & $-0,11$ & 1,64 & $-0,46$ & $-0,0575$ \\
\hline 19 & PT BANK KESAWAN,TBK & 0,35 & 0,23 & $-0,12$ & 0,3 & 0,07 & 0,24 & $-0,06$ & 0,61 & 0,37 & 0,065 \\
\hline 20 & PT BANK SINARMAS,TBK & 0,33 & 0,34 & 0,01 & 0,93 & 0,59 & 1,38 & 0,45 & 1,12 & $-0,26$ & 0,1975 \\
\hline 21 & PT BANK Windu Kentjana international TBK & $\mathbf{1 , 5 4}$ & $\mathbf{0 , 2 5}$ & $-1,29$ & 1,00 & $\mathbf{0 , 7 5}$ & $\mathbf{1 , 0 5}$ & $\mathbf{0 , 0 5}$ & $\mathbf{0 , 9 1}$ & $-0,14$ & $-0,1575$ \\
\hline 22 & PT BANK HIMPUNAN SAUDARA 1906 TBK & 3,73 & 3 & $-0,73$ & 2,43 & $-0,57$ & 2,89 & 0,46 & 3 & $\mathbf{0 , 5 1}$ & $-0,0825$ \\
\hline 23 & PT BANK OF INDIA INDONESIA,TBK & 1,17 & 2,53 & 1,36 & 3,53 & 1 & 2,99 & $-0,54$ & 3,84 & 0,85 & 0,6675 \\
\hline 24 & PT BANK Nusantara Parahayangan, TBK & 1,29 & 1,17 & $-0,12$ & 1,02 & $-0,15$ & 1,4 & 0,38 & 1,57 & 0,17 & 0,07 \\
\hline 25 & PT BANK Pundi Indonesia TBK & $\mathbf{0 , 1 3}$ & -2 & $-2,13$ & $-7,88$ & $-5,88$ & -13 & $-5,12$ & -4 & 9 & $-1,0325$ \\
\hline 26 & PT BANK Agroniaga TBK & 0,39 & 0,45 & 0,06 & 0,49 & 0,04 & 0,55 & 0,06 & 1,41 & 0,86 & 0,255 \\
\hline & JUMLAH & 45,38 & $-17,07$ & $-62,45$ & 33,26 & 50,33 & 33,46 & 0,2 & 46,75 & 13,29 & 0,3425 \\
\hline & \begin{tabular}{|l|} 
RATA-RATA \\
\end{tabular} & 1,75 & $-0,66$ & $-2,40$ & 1,28 & 1,94 & 1,29 & $\mathbf{0 , 0 1}$ & 1,80 & $\mathbf{0 , 5 1 1}$ & $\mathbf{0 , 0 1 3 2}$ \\
\hline
\end{tabular}

sumber : laporan keuangan publikasi Bank Indonesia (* untuk th 2010 dan 2011 per september ) 
Berdasarkan tabel 1.1 dapat dilihat bahwa rata-rata ROA per tahun pada Bank Swasta nasional go public 2007 sampai 2011 mengalami peningkatan. Meskipun demikian, apabila diteliti lebih mendalam ternyata dari 26 bank terdapat 11 bank yang rata-rata trend ROA nya mengalami kenaikan. seperti pada Bank Danamon rata-rata trend ROA menurun sebesar -0,065 ; Bank Mega ratarata trend ROA menurun sebesar $-0,16$; Bank Panin rata-rata trend ROA menurun sebesar -0,33 ;Bank Tabungan Pensiunan rata-rata trend ROA menurun sebesar 0,4275 ; Bank Bumi Arta rata-rata trend ROA menurun sebesar -0,02 ; Bank Pundi Indonesia rata-rata trend ROA menurun sebesar -1,0325 ; Bank Ekonomi Raharja rata-rata trend ROA menurun sebesar $-0,0575$; Bank Windu Kentjana International rata-rata trend ROA menurun sebesar $-0,1575$; Bank mayapada ratarata trend ROA menurun sebesar $-0,0525$; Bank Capital Indonesia rata-rata trend ROA menurun sebesar $-0,2$ dan Bank Saudara rata-rata trend ROA menurun sebesar $-0,0825$. Berdasarkan kenyataan ini jelaslah masih ada masalah tentang profitabilitas yang diukur dengan menggunakan ROA pada bank swasta nasional go public. Sehingga perlu dicari tahu faktor-faktor apa yang bisa mempengaruhi ROA.

Tinggi rendahnya ROA pada suatu bank dapat dipengaruhi oleh kinerja keuangan bank pada aspek Likuiditas, kualitas aktiva, sensitivitas, efisiensi dan solvabilitas.

Lukman Dendawijaya (2009 : 114) mendefinisikan analisis rasio Likuiditas adalah kemampuan bank dalam memenuhi kewajiban-kewajiban jangka pendeknya atau kewajibannya yang sudah jatuh tempo. Agar tidak terjadi 
masalah dalam likuiditas, maka perlu dilakukannya pengawasan dan pengaturan terhadap lembaga perbankan. Tingkat Likuiditas Bank dapat diukur dengan menggunakan Loan To Deposit Ratio (LDR) dan Investing Policy Ratio (IPR).

Apabila LDR digunakan untuk mengukur likuiditas bank maka pengaruh LDR terhadap ROA bank adalah positif. Apabila LDR meningkat, berarti terjadi peningkatan total kredit yang diberikan lebih besar dari peningkatan total dana pihak ketiga. Akibatnya terjadi penurunan pendapatan yang lebih besar daripada penurunan biaya. Dengan begini maka laba bank meningkat dan akibatnya ROA juga naik. Begitu pula sebaliknya, dengan menurunnya LDR maka ROA juga akan ikut mengalami kenaikan. Dengan demikian pengaruh LDR dengan ROA adalah positif.

Sedangkan IPR merupakan rasio yang digunakan untuk tingkat kemampuan bank dalam memenuhi keuangan yang harus segera dipenuhi dengan mengandalkan surat-surat berharga yang dimilikinya. IPR juga berpengaruh positif terhadap ROA, apabila IPR meningkat berarti terjadi peningkatan suratsurat berharga yang di miliki lebih besar dari pada total dana pihak ketiga. akibatnya penempatan pada surat-surat berharga akan meningkatkan pendapatan bank yang lebih besar bila di bandingkan biaya bank. sehingga tingkat profitabilitas bank juga akan meningkat dan ROA ikut meningkat. Dengan demikian pengaruh IPR dengan ROA adalah positif.

Kualitas aktiva adalah kemampuan suatu bank dalam pengelolaan aktiva produktif yang merupakan sumber pendapatan bank yang digunakan untuk membiayai seluruh kegiatan operasional bank (Lukman Dendawijaya 2009:61). 
Kualitas aktiva pada suatu bank dapat diukur dengan rasio keuangan yang antara lain Aktiva Produktif Bermasalah (APB) dan Non Performing Loan (NPL)

Kedua rasio tersebut memiliki pengaruh negatif terhadap ROA suatu bank. Jika APB mengalami peningkatan lebih tinggi, berarti terjadi peningkatan aktiva produktif bermasalah yang lebih besar di banding peningkatan aktiva produktif. Aibatnya terjadi penurunan biaya yang lebih besar daripada penurunan pendapatan.. Sehingga laba menurun dan ROA mengalami kenaikan. Dengan demikian pengaruh APB dengan ROA adalah negatif.

Jika NPL meningkat berarti terjadi peningkatan kredit bermasalah yang lebih besar dari pada total kredit. Akibatnya terjadi penurunan biaya yang lebih besar daripada penurunan pendapatan bank. sehingga laba bank menurun dan akhirnya ROA pun juga ikut turun. Dengan demikian pengaruh NPL dengan ROA dalah negatif.

Sensitivitas menurut Veithzal Rivai (2007 : 725), penilaian sensitivitas terhadap risiko pasar merupakan penilaian terhadap kemampuan modal bank untuk menutupi risiko akibat yang ditimbulkan oleh perubahan risiko pasar dan kecukupan manajemen risiko pasar. Rasio sensitivitas yang umum digunakan adalah Interest Rate Risk (IRR) dan Posisi Devisa Netto (PDN).

Sensitivitas dapat diukur dengan menggunakan Interset Rate Risk (IRR). Antara IRR dan ROA bisa memiliki pengaruh yang positif maupun negatif. ROA akan meningkat dan pengaruhnya positif apabila ISA ( interest sensitive assets) lebih besar dari pada ISL ( interst sensitive liabilities) pada suku bunga naik maka akan menyebabkan penurunan pendapatan yang lebih cepat dari pada 
penurunan biaya sehingga laba meningkat. Dan juga sebaliknya, apabila suku bunga turun maka akan menyebabkan kenaikan pendapatan yang lebih besar dari pada kenaikan biaya, sehingga laba menurun dan ROA menurun sehingga pengaruhnya negatif. Dan apabila ISA lebih kecil dari pada ISL pada saat suku bunga turun akan menyebabkan kenaikan pendapatan pendapatan yang lebih lambat dari pada kenaikan biaya, sehingga laba meningkat dan ROA meningkat maka pengaruhnya negatif. Dan juga sebaliknya bila suku bunga naik maka akan menyebabkan penurunan pendapatan yang lebih lambat daripada penurunan biaya, sehingga laba menurun, ROA menurun sehingga pengaruhnya positif.

Menurut Veitzal Rifai (2007:128) Rasio Efisiensi adalah rasio yang digunakan untuk mengukur kinerja manajemen dalam menggunakan semua faktor-faktor produksi yang dimiliki oleh bank.Untuk dapat mengukur tingkat efisiensi dari kinerja bank dapat menggunakan rasio Beban Operasional terhadap Pendapatan Operasional (BOPO). BOPO meiliki pengaruh yang negatif terhadap ROA suatu bank, semakin tinggi BOPO maka menandakan peningkatan beban operasional yang lebih besar daripada peningkatan pendapatan operasional bank. Akibatnya terjadi penurunan biaya yang lebih besar daripada penurunan pendapatan. Sehingga menyebabkan pendapatan bank menurun dan juga laba bank akan turun dan ROA juga menurun. Dengan demikian pengaruh BOPO dengan ROA adalah negatif.

Rasio Solvabilitas adalah kemampuan bank dalam memenuhi kewajiban jangka panjangnya atau kemampuan bank untuk memenuhi semua kewajiban-kewajiban bank jika terjadi likuidasi (Veithzal Rivai, 2007:723). Untuk 
mengukur tingkat solvabilitas bank, dapat di hitung dengan menggunakan Primary Ratio (PR) dan Fixed Assets to Capital Ratio (FACR). Primary Ratio memiliki pengaruh yang positif teradap ROA, karena ketika Primary Ratio meningkat maka terjadi peningkatan modal yang lebih besar daripada peningkatan total aktiva. Jadi peningkatan modal yang dimiliki lebih besar dibandingkan dengan peningkatan modal yang dialokasikan terhadap total aktiva, akibatnya pendapatan bank meningkat dan menyebabkan keuntungan bank meningkat maka ROA pun akan mengalami peningkatan. Dengan demikian pengaruh PR dengan ROA adalah positif.

FACR memiliki pengaruh yang negatif terhadap ROA, karena ketika FACR meningkat maka berarti peningkatan aktiva tetap lebih besar daripada peningkatan modal, ketika jumlah dana yang dialokasikan ke aktiva tetap semakin meningkat maka tingkat profitabilitas bank akan semakin menurun yang menyebabkan ROA juga mengalami kenaikan. Dengan demikian pengaruh FACR dengan ROA adalah negatif.

Berdasarkan faktor-faktor diatas maka perubahan manajemen bank dalam mengelola tingkat profitabilitas perlu memperhatikan aspek-aspek likuiditas, solvabilitas, efisiensi dan kualitas aktiva.

Dengan acuan pembahasan - pembahasan yang telah dilakukan diatas, maka disimpulkan pihak manajemen bank perlu memberikan perhatian terhadap faktor - faktor yang dapat mempengaruhi profitabilitas bank khususnya ROA, sehingga akan mendapatkan hasil ROA seperti yang diinginkan. 
Berkaitan dengan alasan tersebut diatas maka dalam penelitian ini dipilih judul dengan topik "Pengaruh LDR, IPR, APB, NPL, IRR, BOPO, PR, Dan FACR Terhadap ROA Pada Bank Swasta Nasional Go Public" 


\section{METODE PENELITIAN}

\section{$\underline{\text { Rancangan Penelitian }}$}

Dalam penelitian ini, jenis penelitian yang akan dilakukan dapat ditinjau dari berbagai aspek yaitu ( Nanang Martono,2010 : 14):

1. Dilihat dari teknik pengumpulan data, jenis penelitian ini termasuk penelitian kuantitatif, yaitu mengumpulkan data yang berupa angka, kemudian diolah dan dianalisis untuk mendapatkan suatu informasi ilmiah. Dalam penelitian ini merupakan data laporan keuangan Bank swasta nasional go public di Indonesia berdasarkan tahun 2007 sampai dengan tahun 2011.

2. Jenis data yang digunakan dalam penelitian ini adalah data sekunder. Dimana data sekunder, yaitu penelitian yang memanfaatkan data yang sudah tersedia di lembaga perbankan. Data laporan keuangan selama lima tahun terakhir (2007-2011), literatur, serta data lainnya yang berpengaruh dengan objek penelitian.

3. Penelitian ini termasuk penelitian assosiatif karena penelitian ini merupakan penelitian yang menROA pengaruh antara satu variabel dengan variabel lain yaitu kausal. "Penelitian Kausal bertujuan untuk menyelidiki kemungkinan pengaruh sebab-akibat, tapi tidak dengan jalan eksperimen tetapi dilakukan dengan pengamatan terhadap data dari faktor yang diduga menjadi penyebab, sebagai pembanding”. 


\section{METODE PENELITIAN}

\section{$\underline{\text { Rancangan Penelitian }}$}

Dalam penelitian ini, jenis penelitian yang akan dilakukan dapat ditinjau dari berbagai aspek yaitu ( Nanang Martono,2010 : 14):

4. Dilihat dari teknik pengumpulan data, jenis penelitian ini termasuk penelitian kuantitatif, yaitu mengumpulkan data yang berupa angka, kemudian diolah dan dianalisis untuk mendapatkan suatu informasi ilmiah. Dalam penelitian ini merupakan data laporan keuangan Bank swasta nasional go public di Indonesia berdasarkan tahun 2007 sampai dengan tahun 2011.

5. Jenis data yang digunakan dalam penelitian ini adalah data sekunder. Dimana data sekunder, yaitu penelitian yang memanfaatkan data yang sudah tersedia di lembaga perbankan. Data laporan keuangan selama lima tahun terakhir (2007-2011), literatur, serta data lainnya yang berpengaruh dengan objek penelitian.

6. Penelitian ini termasuk penelitian assosiatif karena penelitian ini merupakan penelitian yang menROA pengaruh antara satu variabel dengan variabel lain yaitu kausal. "Penelitian Kausal bertujuan untuk menyelidiki kemungkinan pengaruh sebab-akibat, tapi tidak dengan jalan eksperimen tetapi dilakukan dengan pengamatan terhadap data dari faktor yang diduga menjadi penyebab, sebagai pembanding". 


\section{$\underline{\text { Batasan Penelitian }}$}

Penelitian ini dibatasi pada aspek tinjauan pengaruh variabel LDR, IPR, APB, NPL, IRR, BOPO, PR, DAN FACR terhadap ROA pada Bank swasta nasional go public pada triwulan I tahun 2007 sampai dengan triwulan IV tahun 2011.

\section{$\underline{\text { Identifikasi Variabel }}$}

Dalam penelitian ini digunakan variabel-variabel yang terdiri dari :

1. Variabel tergantung atau dependent adalah variabel yang disimbolkan dengan Y yaitu ROA

2. Variabel bebas atau independent adalah variabel yang disimbolkan dengan $\mathrm{X}$ yaitu variabel yang mempengaruhi ROA yang terdiri dari :
a. Loan to Deposits Ratio $\left(\mathrm{X}_{1}\right)$
b. investing policy ratio $\left(\mathrm{X}_{2}\right)$
c. Aktiva Produktif Bermasalah $\left(\mathrm{X}_{3}\right)$
d. Non Performing Loan $\left(\mathrm{X}_{4}\right)$
e. Interest Rate Risk $\left(\mathrm{X}_{5}\right)$
f. Beban Operasional terhadap Pendapatan Operasional $\left(\mathrm{X}_{6}\right)$
g. primary ratio $\left(\mathrm{X}_{7}\right)$
h. Fixed asset to Capital Ratio $\left(X_{8}\right)$ 


\section{$\underline{\text { Definisi Operasional dan Pengukuran }}$}

Untuk membatasi permasalahan dalam penelitian ini serta memudahkan dalam menganalisis data, berikut ini akan diuraikan definisi operasional serta pengukuran dari masing - masing variabel.

a. Loan to Deposits Ratio (LDR)

Adalah perbandingan antara total kredit yang diberikan terhadap total simpanan dana pihak ketiga yang dimiliki oleh Bank swasta nasional go public dari triwulan I tahun 2007 sampai dengan triwulan IV tahun 2011 dengan satuan ukurannya adalah persen dan untuk mengukurnya menggunakan rumus nomor (2).

b. Investing policy ratio (IPR)

Rasio ini merupakan hasil perbandingan antara surat-surat berharga dengan total dana pihak ketiga yang dimiliki oleh bank dengan satuan persen pada bank swasta nasional pada periode tahun 2007 sampai dengan Triwulan IV tahun 2011 dan untuk mengukurnya menggunakan rumus nomor (3).

c. Aktiva Produktif Bermasalah (APB)

Adalah perbandingan antara Aktiva Produktif yang bermasalah dengan total Aktiva Produktif yang dimiliki oleh Bank swasta nasional go public mulai triwulan I tahun 2007 sampai dengan triwulan IV 2011 dengan satuan ukurannya adalah persen dan untuk mengukurnya menggunakan rumus nomor (4).

d. Non Performing Loan (NPL) 
Adalah perbandingan antara kredit bermasalah dengan total kredit yang dimiliki oleh Bank swasta nasional go public mulai triwulan I tahun 2007 sampai dengan triwulan IV 2011 dengan satuan ukurannya adalah persen dan untuk mengukurnya menggunakan rumus nomor (5).

e. Inverest Rate Risk (IRR)

Adalah perbandingan antara Interest Rate Sensitivitas Asset (IRSA) dengan Interest Rate Sensitivitas Liablity (IRSL) yang dimiliki oleh Bank swasta nasional go public triwulan I tahun 2007 sampai dengan triwulan IV tahun 2011 dengan satuan ukurannya adalah persen dan untuk mengukurnya menggunakan rumus nomor (10).

f. Beban Operasional Terhadap Pendapatan Operasional (BOPO)

Adalah perbandingan antara beban operasional dengan pendapatan operasional bank yang dimiliki oleh bank swasta nasional mulai triwulan I tahun 2007 sampai dengan Triwulan IV tahun 2011 dengan satuan ukurannya adalah persen dan untuk mengukurnya menggunakan rumus nomor (9).

h. Primary Ratio (PR)

Adalah hasil perbandingan antara modal dengan total asset yang dimiliki oleh Bank swasta nasional Go Public pada setiap twirulanan mulai triwulan I tahun 2007 sampai triwulan IV 2011. Satuan ukurannya persen dan untuk menghitung rasio ini digunakan rumus nomor (12).

i. Fixed Assets to Capital Ratio (FACR) 
Rasio ini merupakan perbandingan antara total aktiva tetap dan inventaris dengan modal bank yang di ukur dengan satuan persen pada bank swasta nasional go public periode tahun 2007 sampai dengan Triwulan IV tahun 2011 dan untuk mengukurnya digunakan rumus nomor (13).

j. Return Of Assets (ROA)

Rasio ini merupakan perbandingan antara laba sebelum pajak dengan total aktiva yang diukur dengan satuan persen pada bank swasta nasional go public periode tahun 2007 sampai dengan triwulan IV tahun 2011 dan untuk mengukurnya digunakan rumus nomor (15).

\subsection{Popolasi, Sampel dan Teknik Pengambilan Sampel}

Dalam penelitian ini, peneliti mengambil data yang populasinya berasal dari bank swasta nasional go public dengan penentuan sampelnya menggunakan teknik purposive sampling yaitu teknik pengambilan sampel yang didasarkan pada kriteria-kriteria tertentu yang ditetapkan sesuai dengan tujuan penelitian.

Berikut daftar total assets Bank Swasta Nasional Go Public per September 2011, diantaranya: 
TABEL 3.1

DAFTAR TOTAL ASSETS BANK SWASTA NASIONAL GO PUBLIC PER SEPTEMBER 2011

\begin{tabular}{|c|c|c|}
\hline NAMA BANK & $\begin{array}{l}\text { total assets (dalam jutaan } \\
\text { rupiah) }\end{array}$ & $\begin{array}{l}\text { rata-rata Trend } \\
\text { ROA }\end{array}$ \\
\hline PT BANK CIMB NIAGA, Tbk & $157,099,326$ & 0,1575 \\
\hline PT BANK BUKOPIN & $49,846,163$ & 0,0075 \\
\hline PT BANK CENTRAL ASIA,TBK & $358,678,424$ & 0,1025 \\
\hline PT BANK DANAMON INDONESIA TBK & $\mathbf{1 2 7 , 5 9 6 , 4 5 8}$ & $-0,065$ \\
\hline PT BANK tabungan pensiunan nasional TBK & $43,413,770$ & $-0,4275$ \\
\hline PT BANK MEGA TBK & $49,959,766$ & $-0,16$ \\
\hline PT BANK OCBC NISP TBK & $55,017,028$ & 0,13 \\
\hline PT BANK PERMATA TBK & $92,902,845$ & 0,0025 \\
\hline PT PAN INDONESIA BANK TBK & $107,862,319$ & $-0,33$ \\
\hline PT BANK Victoria international TBK & $9,164,570$ & 0,36 \\
\hline PT BANK INTERNASIONAL INDONESIA TBK & $86,455,503$ & 0,0075 \\
\hline PT BANK MUTIARA TBK & $12,567,013$ & 0,725 \\
\hline PT BANK ARTHA GRAHA INTERNASIONAL, TBK & $17,423,255$ & 0,1575 \\
\hline PT BANK ICB Bumiputera TBK & $7,352,731$ & 0,0225 \\
\hline PT BANKCapital Indonesia TBK & $4,143,327$ & $-0,2$ \\
\hline PT BANK BUMI ARTA & $2,767,906$ & $-0,02$ \\
\hline PT BANK MAYAPADA INTERNATIONAL, TBK & $12,122,056$ & $-0,0525$ \\
\hline PT BANK EKONOMI RAHARJA,TBK & $22,434,874$ & $-0,0575$ \\
\hline PT BANK KESAWAN,TBK & $3,651,503$ & 0,065 \\
\hline PT BANK SINARMAS,TBK & $15,623,923$ & 0,1975 \\
\hline PT BANK Windu kentjana Internasional TBK & $5,662,773$ & $-0,1575$ \\
\hline PT BANK HIMPUNAN SAUDARA 1906 TBK & $4,178,652$ & $-0,0825$ \\
\hline PT BANK OF INDIA INDONESIA,TBK & $1,841,058$ & 0,6675 \\
\hline PT BANK Nusantara Parahayangan, TBK & $6,282,141$ & 0,007 \\
\hline PT BANK Pundi Indonesia TBK & $4,306,134$ & $-1,0325$ \\
\hline PT BANK Agroniaga TBK & $3,444,980$ & 0,255 \\
\hline
\end{tabular}

Sumber : laporan keuangan publikasi Bank Indonesia

Kriteria penentuan sampel yang digunakan pada penelitian ini adalah Bank yang memiliki Kriteria penentuan sampel yang digunakan pada penelitian ini adalah:

1. Bank yang memiliki asset antara $4 \mathrm{~T}$ sampai dengan $15 \mathrm{~T}$ per september 2011. 
2. Bank bank yang mengalami penurunan trend ROA di tahun 2007 sampai dengan tahun 2011.

3. Bank-bank Swasta Nasional Go Public tersebut masih beroperasi sampai sekarang.

Berdasarkan kriteria tersebut diatas maka sampel yang dipilih pada penelitian ini adalah sebanyak lima bank, yaitu:

TABEL 3.2

DAFTAR BANK SAMPEL TERPILIH

\begin{tabular}{|l|c|l|}
\hline \multicolumn{1}{|c|}{ NAMA BANK } & $\begin{array}{l}\text { total assets (dalam } \\
\text { jutaan rupiah) }\end{array}$ & Rata-rata Trend ROA \\
\hline PT BANKCapital Indonesia TBK & $\mathbf{4 , 1 4 3 , 3 2 7}$ & $-\mathbf{0 , 2}$ \\
\hline PT BANK MAYAPADA INTERNATIONAL, TBK & $\mathbf{1 2 , 1 2 2 , 0 5 6}$ & $-\mathbf{0 , 0 5 2 5}$ \\
\hline PT BANK Windu kentjana Internasional TBK & $\mathbf{5 , 6 6 2 , 7 7 3}$ & $-\mathbf{0 , 1 5 7 5}$ \\
\hline PT BANK HIMPUNAN SAUDARA 1906 TBK & $\mathbf{4 , 1 7 8 , 6 5 2}$ & $-\mathbf{0 , 0 8 2 5}$ \\
\hline PT BANK Pundi Indonesia TBK & $4,306,134$ & $\mathbf{- 1 , 0 3 2 5}$ \\
\hline
\end{tabular}

Sumber: laporan keuangan publikasi Bank Indonesia

Terdapat lima bank yang akan digunakan sebagai sampel penelitian ini yaitu Bank Capital Indonesia Tbk, Bank Mayapada International Tbk, Bank Windu Kentjana International Tbk, Bank Himpunan Saudara Tbk dan Bank Pundi Indonesia Tbk.

\section{Data dan Metode Pengumpulan Data}

Data yang dianalisis dalam penelitian ini adalah data sekunder yang bersifat kuantitatif yang diambil dari laporan keuangan triwulanan mulai dari triwulan IV tahun 2007 sampai dengan triwulan IV tahun 2011 dari Bank swasta nasional go public yang terdiri dari Bank Capital Indonesia Tbk, Bank Mayapada 
International Tbk, Bank Windu Kentjana International Tbk, Bank Himpunan Saudara Tbk dan Bank Pundi Indonesia Tbk.

Metode yang digunakan dalam penelitian ini adalah metode dokumentasi karena data yang dikumpulkan adalah berupa data sekunder dalam bentuk laporan keuangan Bank swasta nasional go public yang diperoleh dari laporan- laporan keuangan yang terdapat pada Bank Indonesia.

\subsection{Teknik Analisis Data}

Teknik analisis data yang digunakan pada swasta nasional go public meliputi analisis deskriptif dan analisis statistik. Analisis deskriptif berfungsi untuk mendiskripsikan pengaruh antar variabel bebas dengan variabel tergantung sadangkan analisis statistik berfungsi untuk menganalisis data dengan menggunakan regresi linier berganda dimana model ini bertujuan untuk mengetahui seberapa besar pengaruh variabel Loan to Deposit Ratio (LDR), Investing Policy Ratio (IPR), Aktiva Produktif Bermasalah (APB), Net Performing Loan (NPL), Interest Rate Risk (IRR) dan , Beban Operasional terhadap Pendapatan Operasional (BOPO), Primary Ratio (PR) dan Fixed Asset to Capital Ratio (FACR), terhadap ROA karena diamsumsikan variabel tersebut memiliki pengaruh linier. Maka dari itu dilakukan analisis dengan langkahlangkah sebagai berikut :.

1. Melakukan analisis deskriptif

Ini dilakukan untuk mengetahui perkembangan rasio-rasio empat Bank swasta nasional go public mulai dari triwulan I tahun 2007 sampai dengan triwulan IV tahun 2011. 
2. Melakukan analisis infernsial untuk menguji hipotesis

Langkah-langkah yang dilakukan dalam pengujian hipotesis sebagai berikut :

a. Analisis Regresi Berganda

Analisis regresi dilakukan untuk menentukan arah dan besarnya pengaruh variable-variabel bebas $(\mathrm{X})$ terhadap variabel tergantung $(\mathrm{Y})$ dengan persamaan regresi sebagai berikut :

$Y=\alpha+\beta_{1} X_{1}+\beta_{2} X_{2}+\beta_{3} X_{3}+\beta_{4} X_{4}+\beta_{5} X_{5}+\beta_{6} X_{6}+\beta_{7} X_{7}+\beta_{8} X_{8}+$ ei

Dimana :

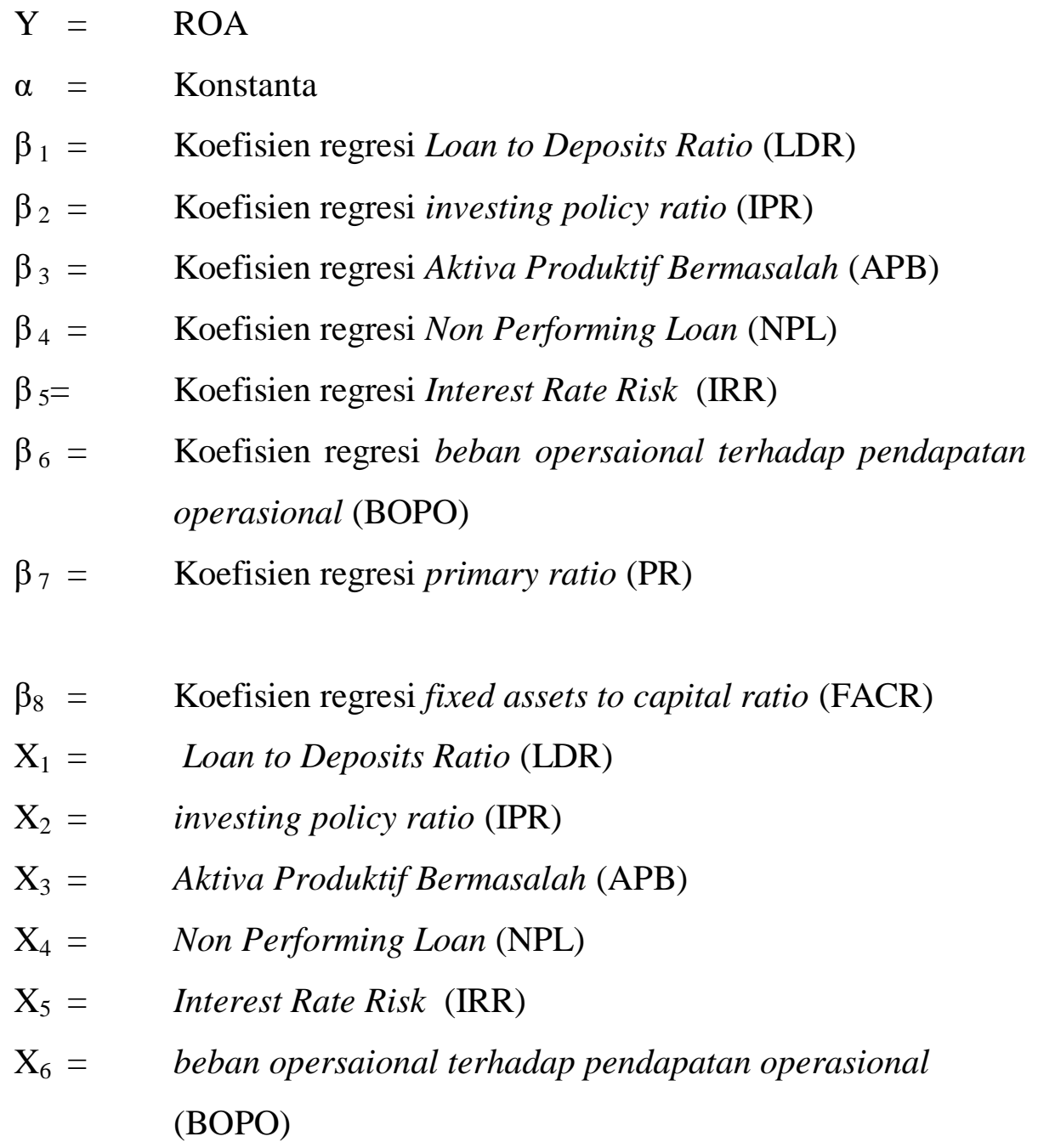


$\mathrm{X}_{7}=\quad$ primary ratio $(\mathrm{PR})$

$\mathrm{X}_{8}=\quad$ fixed assets to capital ratio (FACR)

ei $=\quad$ Error $($ variabel pengganggu di luar variabel $)$

b. Melakukan Uji Serempak ( Uji F)

Uji $F$ ini dilakukan untuk mengetahui signifikan atau tidaknya pengaruh variabel $\mathrm{X}$ (variabel bebas) secara bersama-sama terhadap variabel Y (variabel tergantung). Langkah-langkah yang dilakukan dalam pengujian ini adalah sebagai berikut :

1. Menentukan hipotesis statistik

Ho : $\beta_{1}=\beta_{2}, \beta_{3}=\beta_{4}=\beta_{5}=\beta_{6}=\beta_{7}=\beta_{8}=0$

Artinya semua variabel bebas $\left(\mathrm{X}_{1}, \mathrm{X}_{2}, \mathrm{X}_{3}, \mathrm{X}_{4}, \mathrm{X}_{5}, \mathrm{X}_{6}, \mathrm{X}_{7}, \mathrm{X}_{8}\right)$ secara bersama-sama mempunyai pengaruh yang tidak signifikan terhadap variabel tidak bebas (tergantung).

$\mathrm{Hi}: \beta_{1}=\beta_{2}=\beta_{3}=\beta_{4}=\beta_{5}=\beta_{6}=\beta_{7}=\beta_{8}=0$

Artinya semua variabel bebas secara bersama-sama mempunyai pengaruh yang signifikan terhadap variabel tergantung.

2. Menentukan level yang signifikan ( $\alpha$ ) sebesar 5\%

3. Menentukan daerah penerimaan dan penolakan $\left(\mathrm{H}_{0}\right)$ 


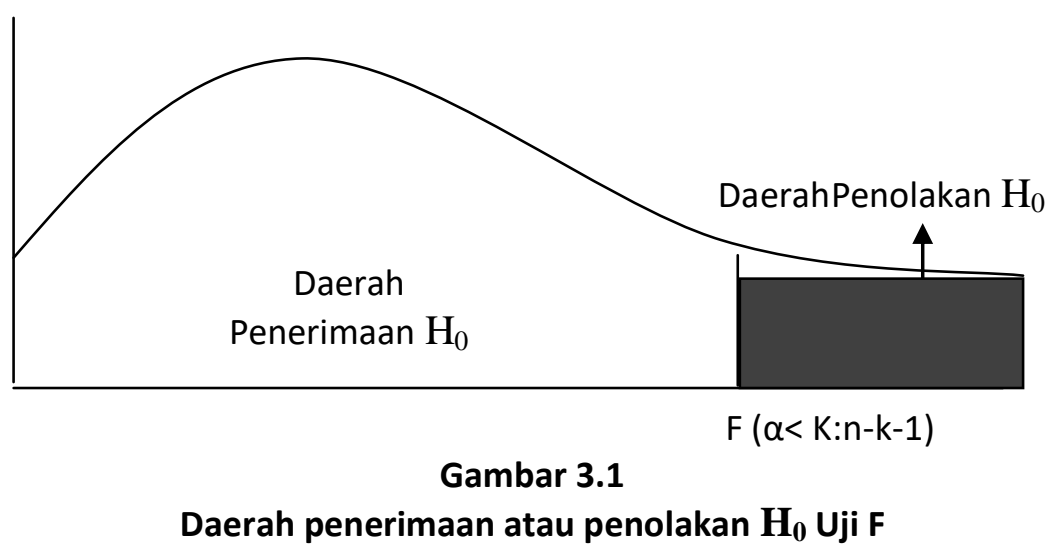

4. Menghitung $F_{\text {hitung }}$ dengan rumus :

$\mathrm{F}=\frac{S S R / K}{\operatorname{SSE} /(\mathrm{n}-k-1)}$

Dimana :

$\mathrm{SSR}=$ Sum of Square from the regression

$\mathrm{k}=$ Jumlah Variabel bebas $(\mathrm{X})$

$\mathrm{SSE}=$ Sum of Square from the error

$\mathrm{n} \quad=$ Jumlah data

5. Menarik kesimpulan

Kesimpulan $\mathrm{H}_{0}$ diterima dan $\mathrm{H}_{0}$ ditolak berdasarkan pada hasil perbandingan antara $\mathrm{F}$ hitung dan $\mathrm{F}$ tabel dengan kriteria pengujian sebagai berikut :

a) $\mathrm{H}_{0}$ diterima jika $: \mathrm{F}_{\text {hitung }} \leq \mathrm{F}_{\text {tabel }}$

Artinya variabel bebas $(\mathrm{X})$ secara bersama-sama mempunyai pengaruh yang tidak signifikan terhadap variabel tergantung $(\mathrm{Y})$.

b) $\mathrm{H}_{0}$ ditolak jika : $\mathrm{F}_{\text {hitung }}>\mathrm{F}_{\text {tabel }}$ 
Artinya variabel bebas (X) secara bersama-sama mempunyai pengaruh variabel bebas $(\mathrm{X})$ secara individu terhadap variabel tergantung (Y).

c. Melakukan Uji Parsial ( Uji t )

Uji t ini dilakukan untuk menguji siginifikan atau tidaknya pengaruh variabel bebas $(\mathrm{X})$ secara individu terhadap variabel tergantung $(\mathrm{Y})$. Dalam penelitian ini dilakukan uji satu sisi dan dua sisi yaitu :

a. Uji satu sisi kanan untuk variabel yang mempunyai pengaruh positif.

1. Menentukan hipotesis statistik

a) $\mathrm{H}_{0}: \beta \mathrm{i} \leq 0$

Artinya variabel bebas $\left(\mathrm{X}_{1}, \mathrm{X}_{2}, \mathrm{X}_{7}\right)$ secara parsial mempunyai pengaruh positif yang tidak siginifikan terhadap variabel tergantung $(\mathrm{Y})$.

b) $\mathrm{H}_{1}: \beta \mathrm{i}>0$

Artinya variabel bebas $\left(\mathrm{X}_{1}, \mathrm{X}_{2}, \mathrm{X}_{7}\right)$ secara parsial mempunyai pengaruh positif yang siginifikan terhadap variabel tergantung $(\mathrm{Y})$

2. Menentukan taraf signifikan $(\alpha)$ sebesar 5\%

3. Menentukan daerah penerimaan dan penolakan $\left(\mathrm{H}_{0}\right)$ 


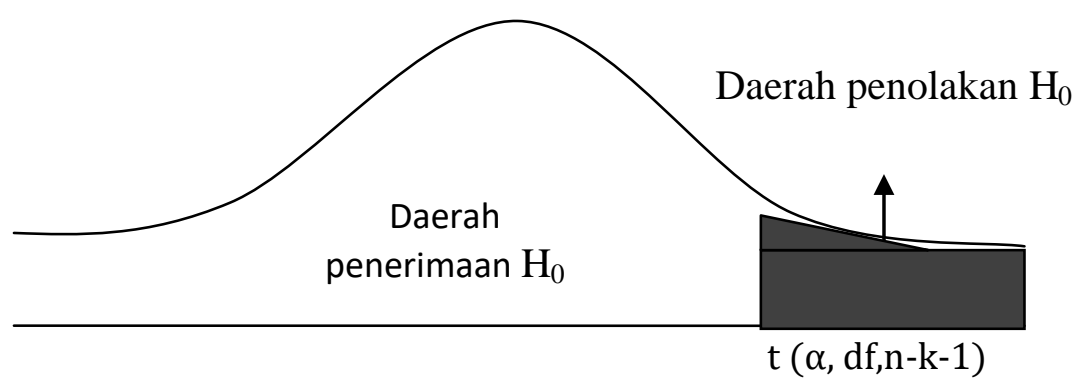

Gambar 3.2

Daerah Penerimaan $\mathrm{H}_{0}$ dan Penolakan $\mathrm{H}_{0}$ Uji $\mathrm{t}$ sisi Kanan

4. Menentukan $\mathrm{t}$ hitung dengan menggunakan rumus sebagai berikut:

$\mathrm{t}=\frac{b i}{S \cdot b i}$

Dimana :

$\mathrm{b}_{\mathrm{i}}=$ Koefisien regresi variabel $\mathrm{X}_{1}, \mathrm{X}_{2}, \mathrm{X}_{3}, \mathrm{X}_{4}, \mathrm{X}_{5}, \mathrm{X}_{6}, \mathrm{X}_{7}, \mathrm{X}_{8}, \mathrm{X}_{9}$

$\mathrm{S} . \mathrm{b}_{\mathrm{i}} \quad=$ Standar error koefisien regresi

5. Menarik kesimpulan

a) $\mathrm{H}_{0}$ diterima jika : $\mathrm{t}_{\text {hitung }} \leq-\mathrm{t}_{\text {tabel }}$

Artinya variabel bebas (X) secara parsial mempunyai pengaruh positif yang tidak signifikan terhadap variabel tergantung (Y).

b) $\mathrm{H}_{0}$ ditolak jika : $\mathrm{t}_{\text {hitung }}>-\mathrm{t}_{\text {tabel }}$

Artinya variabel bebas (X) secara parsial mempunyai pengaruh positif yang signifikan terhadap variabel tergantung (Y).

b. Uji satu sisi kiri yang mempunyai pengaruh negatif

1. Merumuskan formulasi atau uji hipotesis 
a. $\mathrm{H}_{0}: \beta \mathrm{i} \geq 0$

Artinya variabel bebas $\left(\mathrm{X}_{3}, \mathrm{X}_{4}, \mathrm{X}_{6}, \mathrm{X}_{8}\right)$ secara parsial mempunyai pengaruh negatif yang tidak signifikan terhadap variabel tergantung (Y).

b. $\mathrm{Hi}: \beta \mathrm{i}<0$

Artinya variabel bebas $\left(\mathrm{X}_{3}, \mathrm{X}_{4}, \mathrm{X}_{6}, \mathrm{X}_{8}\right)$ secara parsial mempunyai pengaruh negatif yang signifikan terhadap variabel tergantung $(\mathrm{Y})$.

2. Menentukan taraf signifikan $(\alpha)$ sebesar 5\%

3. Menentukan daerah penerimaan dan penolakan (Ho)

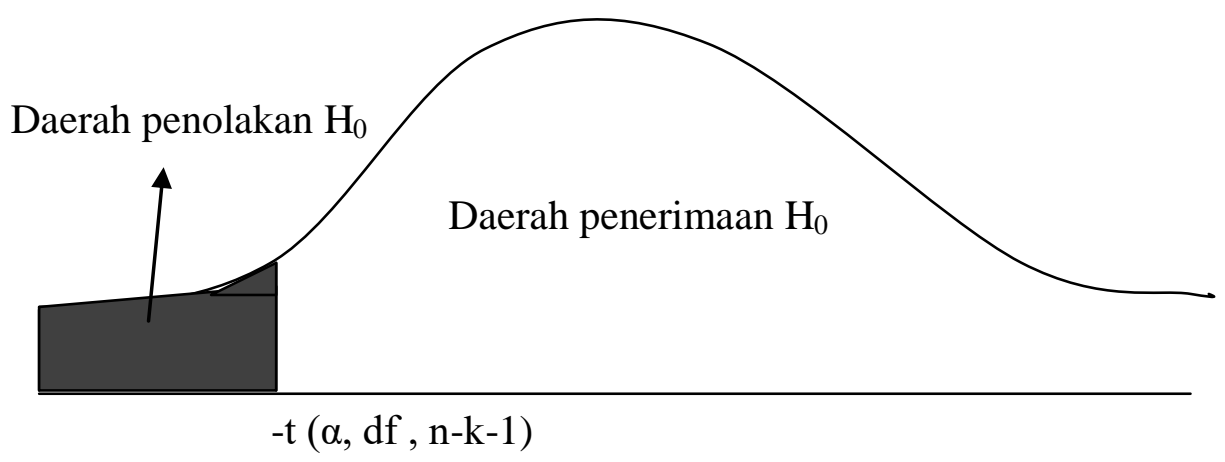

Gambar 3.3

Daerah penolakan dan penerimaan $\mathrm{H}_{0}$ uji t sisi kiri

4. Menentukan $\mathrm{t}$ hitung dengan menggunakan rumus sebagai berikut:

$\mathrm{t}=\frac{b i}{S \cdot b i}$

Dimana :

$b_{i} \quad=\quad$ Koefisien $\quad$ regresi variabel

$\mathrm{X}_{1}, \mathrm{X}_{2}, \mathrm{X}_{3}, \mathrm{X}_{4}, \mathrm{X}_{5}, \mathrm{X}_{6}, \mathrm{X}_{7}, \mathrm{X}_{8}$, 
S . $b_{\mathrm{i}} \quad=$ Standar error koefisien regresi

5. Menarik kesimpulan

a) $\mathrm{H}_{0}$ diterima jika $: t_{\text {hitung }} \geq-t_{\text {tabel }}$

Artinya variabel bebas (X) secara parsial mempunyai pengaruh negatif yang tidak signifikan terhadap variabel tergantung (Y).

b) $\mathrm{H}_{0}$ ditolak jika : $\mathrm{t}_{\text {hitung }}<-\mathrm{t}_{\text {tabel }}$

Artinya variabel bebas (X) secara parsial mempunyai pengaruh negatif yang signifikan terhadap variabel tergantung (Y).

c. Uji dua sisi yang mempunyai pengaruh negatif / posistif

Digunakan untuk melakukan pengujian terhadap variabel yang mempunyai pengaruh negatif dan positif

1. Merumuskan formulasi atau uji hipotesis

a. $\mathrm{H}_{0}: \beta \mathrm{i}=0$

Artinya variabel bebas $\left(\mathrm{X}_{5}\right)$ secara parsial mempunyai pengaruh yang tidak signifikan terhadap variabel tergantung (Y).

b. Hi : $\beta \mathrm{i} \neq 0$ Artinya variabel bebas $\left(\mathrm{X}_{5}\right)$ secara parsial mempunyai pengaruh yang tidak signifikan terhadap variabel tergantung (Y).

2. Menentukan taraf signifikan $(\alpha)$ sebesar $5 \%$

3. Menentukan daerah penerimaan dan penolakan $\left(\mathrm{H}_{0}\right)$ 


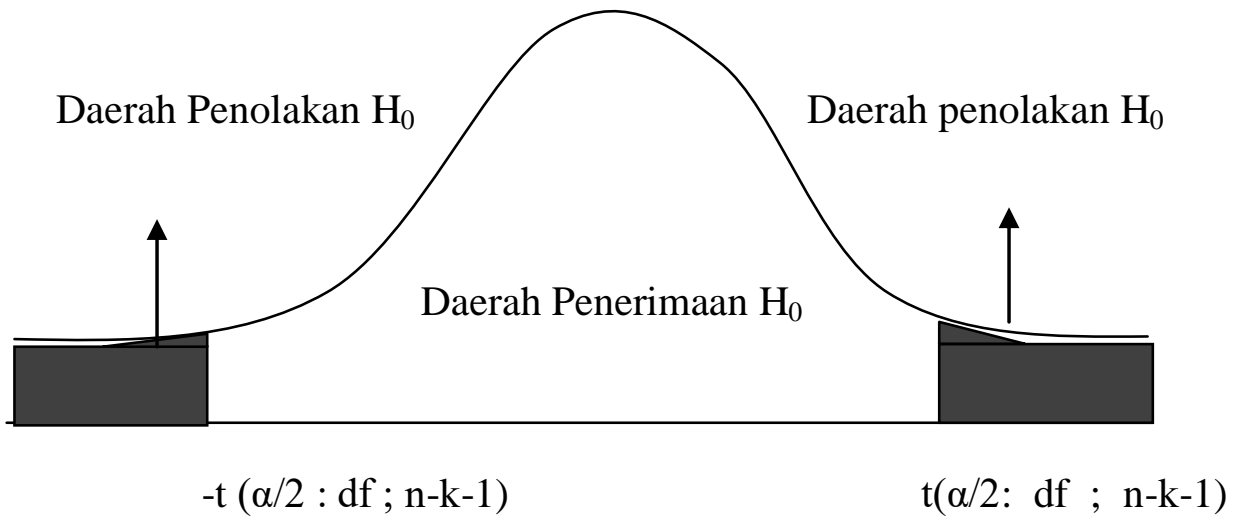

Gambar 3.4

Daerah penolakan dan penerimaan $\mathrm{H}_{0}$ uji $\mathrm{t}$ dua sisi

4. Menentukan $t$ hitung dengan menggunakan rumus sebagai berikut:

$\mathrm{t}=\frac{b i}{S \cdot b i}$

Dimana

$b_{i}=$ Koefisien regresi variabel $X_{1}, X_{2}, X_{3}, X_{4}, X_{5}, X_{6}, X_{7}, X_{8}$,

S . $b_{i} \quad=$ Standar error koefisien regresi

5. Menarik kesimpulan

a) $\mathrm{H}_{0}$ diterima : $-\mathrm{t}_{\text {tabel }} \leq \mathrm{t}_{\text {hitung }} \leq \mathrm{t}_{\text {tabel }}$

Artinya variabel bebas (X) secara parsial mempunyai pengaruh yang tidak signifikan terhadap variabel tergantung $(\mathrm{Y})$.

b) Ho ditolak jika : - $\mathrm{t}_{\text {tabel }}<\mathrm{t}_{\text {hitung }}$, atau $\mathrm{t}_{\text {hitung }}<\mathrm{t}_{\text {tabel }}$ 
Artinya variabel bebas (X) secara parsial mempunyai pengaruh yang tidak signifikan terhadap variabel tergantung(Y) 


\section{Pembahasan}

Berdasarkan hasil dari analisis regresi linear berganda, uji $\mathrm{F}$ dan uji $\mathrm{t}$ dengan menggunakan software SPSS versi 11.5 for windows, maka selanjutnya akan dilakukan pembahasan sebagai berikut :

\section{Hasil Analisis Regresi Linear Berganda}

Berdasarkan hasil analisis regresi linear berganda diatas, maka dapat diketahui diantara kedelapan variabel bebas yang menjadi sampel penelitian ini terdiri dari LDR, IPR, APB, NPL, IRR, BOPO, PR dan FACR terdapat dua variabel bebas yang mempunyai ketidaksesuaian nilai koeifisien regresi linear berganda dengan teori yaitu variabel IPR dan FACR. Sementara itu variabel tergantung dalam penelitian ini ROA mengalami penurunan, ini disebabkan oleh penurunan laba sebelum pajak yang lebih besar daripada total asset. Sehingga biaya meningkat lebih besar daripada pendapatan. Selanjutnya akan dilakukan pembahasan mengenai masing-masing nilai koeifisien regresi linear berganda pada masingmasing variabel bebas seperti yang tersaji dalam tabel 4.13.

Secara rinci hubungan dari kedepalan variabel bebas terhadap variabel terikat dalam penelitian ini menurut tabel 4.13 adalah sebagai berikut :

Tabel. 4.13

RANGKUMAN HASIL UJI PARSIAL

\begin{tabular}{|l|l|l|l|l|}
\hline Variabel & Kesimpulan & Teori & Hasil penelitian & Kesesuaian Teori \\
\hline LDR & $\mathrm{H}_{0}$ Ditolak & Positif & Positif & sesuai \\
\hline IPR & $\mathrm{H}_{0}$ Diterima & Positif & Negatif & Tidak sesuai \\
\hline APB & $\mathrm{H}_{0}$ Ditolak & Negatif & Negatif & Sesuai \\
\hline NPL & $\mathrm{H}_{0}$ Diterima & Negatif & Negatif & Sesuai \\
\hline
\end{tabular}




\begin{tabular}{|l|l|l|l|l|}
\hline IRR & $\mathrm{H}_{0}$ Ditolak & Positif / Negatif & Negatif & Sesuai \\
\hline BOPO & $\mathrm{H}_{0}$ Ditolak & Negatif & Negatif & sesuai \\
\hline PR & $\mathrm{H}_{0}$ Diterima & Positif & Positif & sesuai \\
\hline FACR & $\mathrm{H}_{0}$ Diterima & Negatif & Positif & Tidak sesuai \\
\hline
\end{tabular}

Sumber data diolah dari spss

a. Hubungan antara LDR dengan ROA

Secara teori, pengaruh LDR terhadap ROA adalah positif atau searah. Hasil penelitian diperoleh bahwa koefisien regresi untuk LDR adalah 0,020 yang berarti hasil penelitian menunjukkan adanya pengaruh positif LDR terhadap ROA. Jadi hal ini sesuai dengan teori. Kesesuaian penelitian ini dengan teori disebabkan karena LDR bank sampel penelitian mengalami penurunan sementara ROA bank sampel penelitian juga mengalami penurunan. turunnya LDR secara teori disebabkan oleh peningkatan KYD lebih kecil daripada kenaikan DPK sehingga pendapatan bunga meningkat lebih kecil daripada peningkatan biaya bunga dan laba akan turun sehingga ROA juga menurun.

Perbandingan hasil penelitian ini tidak sesuai dengan penelitian yang dilakukan oleh Mertika Kirana Rimadhani (2010) dan winda ayu wijayanti (2011) yang menyatakan bahwa LDR memiliki hubungan positif yang tidak signifikan terhadap variabel ROA.

b. Hubungan antara IPR dengan ROA

Secara teori, pengaruh IPR terhadap ROA adalah positif atau searah. Hasil penelitian diperoleh bahwa koefisien regresi untuk IPR adalah -0,009 yang berarti hasil penelitian menunjukkan adanya pengaruh negatif terhadap ROA. Jadi hal ini tidak sesuai dengan teori. Ketidaksesuaian ini dikarenakan adanya kenaikan IPR. Ketidaksesuaian penelitian ini dengan teori disebabkan karena IPR 
yang mengalami peningkatan berarti kenaikan surat berharga lebih besar daripada kenaikan DPK sehingga pendapatan bunga meningkat lebih besar daripada peningkatan biaya bunga dan laba akan naik sehingga ROA juga naik. Tetapi pada penelitian ini, ROA justru menurun karena ada peningkatan pada biaya operasional lain yang lebih tinggi yang menyebabkan laba menurun dan ROA ikut menurun.

Perbandingan hasil penelitian ini sesuai dengan penelitian yang dilakukan oleh Mertika Kirana Rimadhani (2010) dan Winda Ayu Wijayanti (2011) yang menyatakan bahwa IPR memiliki hubungan positif yang tidak signifikan terhadap variabel ROA di tolak.

c. Hubungan antara APB dengan ROA

Secara teori, pengaruh APB terhadap ROA adalah negatif. Hasil penelitian diperoleh bahwa koefisien regresi untuk APB adalah -0,140, yang berarti hasil penelitian menunjukkan adanya pengaruh negatif terhadap ROA. Jadi hal ini sesuai dengan teori. Kesesuaian ini dikarenakan adanya peningkatan APB yang berarti peningkatan aktiva produktif bermasalah yang lebih besar dibandingkan dengan peningkatan aktiva produktif sehingga peningkatan biaya pencadangan lebih besar dibandingkan dengan pendapatan bunga sehingga laba menurun dan ROA menurun.

Perbandingan hasil penelitian ini sesuai dengan penelitian yang dilakukan oleh Mertika Kirana Rimadhani (2010) yang menyatakan bahwa APB memiliki hubungan negatif terhadap ROA. sedangkan Perbandingan hasil penelitian ini tidak sesuai dengan penelitian yang dilakukan Winda Ayu Wijayanti 
(2011) yang menyatakan bahwa APB memiliki hubungan yang tidak signifikan terhadap variabel ROA.

d. Hubungan antara NPL dengan ROA

Secara teori, pengaruh NPL terhadap ROA adalah negatif. Hasil penelitian diperoleh bahwa koefisien regresi untuk NPL adalah -0,001, yang berarti hasil penelitian menunjukkan adanya pengaruh negatif terhadap ROA. Jadi hal ini sesuai dengan teori. kesesuaian ini dikarenakan Dimana NPL mengalami peningkatan berarti kenaikan kredit bermasalah lebih besar dibandingkan kenaikan kredit menyebabkan kenaikan biaya pencadangan lebih besar dibanding kenaikan pendapatan bunga. Laba menurun sehingga ROA juga ikut menurun.

Perbandingan hasil penelitian ini tidak sesuai dengan penelitian yang dilakukan oleh Mertika Kirana Rimadhani (2010) dan Winda Ayu Wijayanti (2011) yang menyatakan bahwa NPL memiliki hubungan negatif yang tidak signifikan terhadap variabel ROA.

e. Hubungan antara IRR dengan ROA

Secara teori, pengaruh IRR terhadap ROA adalah bisa positif ataupun negatif. Hasil penelitian diperoleh bahwa koefisien regresi untuk IRR adalah 0.018, yang berarti hasil penelitian menunjukkan adanya pengaruh negatif terhadap ROA. Kesesuaian ini dikarenakan Dimana IRR secara rata-rata mengalami penurunan yang berarti kenaikan ISA lebih kecil daripada kenaikan ISL. Jika tingkat bunga mengalami penurunan maka kenaikan pendapatan lebih kecil daripada kenaikan biaya. Dan hal tersebut akan menyebabkan penurunan profit sehingga ROA juga turun. 


\section{f. Hubungan BOPO dengan ROA}

Secara teori, pengaruh BOPO terhadap ROA adalah negatif. Hasil penelitian diperoleh bahwa koefisien regresi untuk BOPO adalah $-0,105$, yang berarti hasil penelitian menunjukkan adanya pengaruh negatif terhadap ROA. Kesesuaian ini dikarenakan adanya peningkatan BOPO yang berarti terjadi peningkatan biaya operasional yang lebih besar daripada peningkatan pendapatan operasional, akibatnya terjadi kenaikan biaya yang lebih tinggi di bandingkan kenaikan pendapatan sehingga laba bank akan menurun, begitu pula ROA juga akan ikut menurun.

Perbandingan hasil penelitian ini sesuai dengan penelitian yang dilakukan oleh Mertika Kirana Rimadhani (2010) dan Winda Ayu Wijayanti (2011) yang menyatakan bahwa BOPO memiliki hubungan negatif yang signifikan terhadap variabel ROA.

g. Hubungan antara PR dengan ROA

Secara teori, pengaruh PR terhadap ROA adalah positif. Hasil penelitian diperoleh bahwa koefisien regresi untuk PR adalah 0,018, yang berarti hasil penelitian menunjukkan adanya pengaruh positif terhadap ROA. Kesesuaian ini dikarenakan adanya kenaikan modal yang lebih kecil di bandingkan peningkatan aktiva tetap. Akibatnya terjadi kenaikan biaya yang lebih tinggi di bandingkan kenaikan pendapatan sehingga laba bank akan menurun, begitu pula ROA juga akan ikut menurun.

Perbandingan hasil penelitian ini sesuai dengan penelitian yang dilakukan oleh Winda Ayu Wijayanti (2011) yang menyatakan bahwa PR 
memiliki hubungan positif yang tidak signifikan terhadap variabel ROA. Sedangkan untuk peneliti terdahulu Kirana Rimadhani (2010) tidak menggunakan variabel PR.

h. Hubungan antara FACR dengan ROA

Secara teori, pengaruh FACR terhadap ROA adalah negatif. Hasil penelitian diperoleh bahwa koefisien regresi untuk FACR adalah 0,023, yang berarti hasil penelitian menunjukkan adanya pengaruh positif terhadap ROA. Jadi hal ini tidak sesuai dengan teori. Ketidaksesuaian ini dikarenakan Dimana FACR secara rata-rata mengalami penurunan yang berarti kenaikan aktiva tetap lebih kecil daripada kenaikan modal. Dengan penurunan aktiva tetap berarti alokasi dana untuk aktiva tetapnya juga menurun. Sehingga alokasi untuk aktiva produktifnya naik menyebabkan biaya menurun dan pendapatan juga naik. Dengan naiknya pendapatan operasional menyebabkan kenaikan profit sehingga ROA juga ikut naik. Tetapi pada penelitian ini, ROA justru menurun karena ada peningkatan pada biaya operasional lain yang lebih tinggi yang menyebabkan laba menurun dan ROA ikut menurun.

Perbandingan hasil penelitian ini sesuai dengan penelitian yang dilakukan oleh Mertika Kirana Rimadhani (2010) yang menyatakan bahwa FACR memiliki hubungan negatif yang tidak signifikan terhadap variabel ROA. Sedangkan untuk peneliti terdahulu Winda Ayu Wijayanti (2011) tidak menggunakan variabel FACR. 


\section{Kesimpulan}

Berdasarkan analisis data dan pengujian hipotesis yang telah dilakukan maka kesimpulan yang dapat ditarik adalah sebagai berikut :

1. Variabel bebas LDR, IPR, APB, NPL, IRR, BOPO, PR, dan FACR secara bersama-sama mempunyai pengaruh yang signifikan terhadap ROA pada Bank Swasta Nasional Go Public. Besarnya pengaruh variabel LDR, IPR, APB, NPL, IRR, BOPO, PR, dan FACR tersebut adalah 90,4 persen yang disebabkan oleh variabel bebas secara bersanma-sama, sedangkan sisanya sebesar 9,6 persen disebabkan variabel-variabel lain diluar variabel bebas. Dengan demikian hipotesis pertama yang menyatakan bahwa LDR, IPR, APB, NPL, IRR, BOPO, PR, dan FACR secara bersama-sama tehadap ROA pada Bank Swasta Nasional Go Public dinyatakan diterima.

2. Variabel LDR secara parsial mempunyai pengaruh positif yang signifikan terhadap ROA pada Bank Swasta Nasional Go Public. Besarnya pengaruh LDR terhadap ROA adalah sebesar 3,09 persen. Dengan demikian berarti hipotesis kedua yang menyatakan bahwa LDR secara individu mempunyai pengaruh positif yang signifikan terhadap ROA pada Bank Swasta Nasional Go Public dinyatakan diterima.

3. Variabel IPR secara parsial mempunyai pengaruh negatif yang tidak signifikan terhadap ROA pada Bank Swasta Nasional Go Public. Besarnya pengaruh IPR adalah sebesar 0,56 persen. Dengan demikian hipotesis yang ketiga menyatakan bahwa IPR secara individu mempunyai pengaruh positif 
yang signifikan terhadap ROA pada Bank Swasta Nasional Go Public dinyatakan ditolak.

4. Variabel APB secara parsial mempunyai pengaruh negatif yang signifikan terhadap ROA pada Bank Swasta Nasional Go Public. Besarnya pengaruh APB adalah sebasar 30,80 persen. Dengan demikian hipotesis keempat yang menyatakan bahwa variabel APB secara individu mempunyai pengaruh negatif yang signifikan terhadap ROA pada Bank Swasta Nasional Go Public dinyatakan diterima.

5. Variabel NPL secara parsial mempunyai pengaruh negatif yang tidak signifikan terhadap ROA pada Bank Swasta Nasional Go Public. Besarnya pengaruh NPL terhadap ROA adalah sebesar 0,07 persen. Dengan demikian hipotesis kelima yang menyatakan bahwa NPL secara individu mempunyai pengaruh negatif yang signifikan terhadap ROA pada Bank Swasta Nasional Go Public dinyatakan ditolak.

6. Variabel IRR secara parsial mempunyai pengaruh negatif yang signifikan terhadap ROA pada Bank Swasta Nasional Go Public. Besarnya pengaruh IRR adalah sebesar 0,01 persen. Dengan demikian hipotesis ke enam yang menyatakan bahwa IRR secara individu mempunyai pengaruh yang signifikan terhadap ROA pada Bank Swasta Nasional Go Public dinyatakan diterima.

7. Variabel BOPO secara parsial mempunyai pengaruh negatif yang signifikan terhadap ROA pada Bank Swasta Nasional Go Public. Besarnya pengaruh BOPO adalah sebesar 51,26 persen. Dengan demikian hipotesis ketujuh yang 
menyatakan bahwa BOPO secara individu mempunyai pengaruh negatif yang signifikan terhadap ROA pada Bank Swasta Nasional Go Public dinyatakan diterima.

8. Variabel PR secara parsial mempunyai pengaruh positif yang tidak signifikan terhadap ROA pada Bank Swasta Nasional Go Public. Besarnya pengaruh PR adalah sebesar 2,43 persen. Dengan demikian hipotesis kedelapan yang menyatakan bahwa PR secara individu mempunyai pengaruh positif yang signifikan terhadap ROA pada Bank Swasta Nasional Go Public dinyatakan ditolak.

9. Variabel FACR secara parsial mempunyai pengaruh positif yang tidak signifikan terhadap ROA pada Bank Swasta Nasional Go Public. Besarnya pengaruh FACR adalah sebesar 30,3 persen. Dengan demikian hipotesis kedelapan yang menyatakan bahwa FACR secara individu mempunyai pengaruh negatif yang signifikan terhadap ROA pada Bank Swasta Nasional Go Public dinyatakan ditolak.

10. Variabel yang memiliki pengaruh dominan terhadap terhadap ROA pada Bank Swasta Nasional Go Public adalah BOPO dengan kontribusi sebesar 51,26 persen. 


\section{$\underline{\text { Keterbatasan Penelitian }}$}

Penulis menyadari bahwa penelitian yang telah dilakukan memilikiketerbatasanketerbatasan. Adapun keterbatasan-keterbatasan dalam penelitian ini.

1. Subjek penelitian yang digunakan adalah Bank Swasta Nasional Go public berdasarkan kriteria total asset antara 4 Triliun sampai dengan 15 Triliun per September 2011.

2. Periode penelitian yang digunakan selama lima tahun yaitu yang dimulai dari triwulan I tahun 2007 sampai dengan triwulan IV tahun 2011.

3. Jumlah variabel yang diteliti terbatas, meliputi LDR, IPR, APB, NPL, IRR, BOPO, PR, DAN FACR

\section{$\underline{\text { Saran }}$}

Berdasarkan hasil penelitian ini maka dapat diberikan saran yang diharapkan dapat bermanfaat bagi berbagai pihak yang memiliki kepentingan dengan hasil penelitian diantaranya :

1. Variabel yang dominan yaitu BOPO, sebaiknya untuk semua Bank Swasta Nasional Go Public yang termasuk dalam sampel penelitian seperti pada Bank Capital Indonesia, Bank Mayapada International, Bank Himpunan Saudara, Bank Windu Kentjana International dan Bank Pundi Indonesia harus bisa meningkatkan kinerja effisiensi dalam manajemen Bank terutama pada aspek pengurangan biaya operasional yang dikeluarkan oleh Bank agar pendapatan operasionalnya yang didapat lebih besar daripada biaya operasional yang dikeluarkan. 
2. Kebijakan yang terkait dengan ROA, sebaiknya untuk semua Bank Swasta Nasional Go Public yang termasuk dalam sampel penelitian seperti pada Bank Capital Indonesia, Bank Mayapada International, Bank Himpunan Saudara, Bank Windu Kentjana International dan Bank Pundi Indonesia harus bisa memperbaiki tingkat efisiensi pengelolaan assetnya agar dapat meningkatkan jumlah ROA dan juga dapat meningkatkan laba.

\section{Bagi Peneliti Selanjutnya}

Peneliti selanjutnya yang mengambil tema sejenis, sebaiknya menambah periode penelitian dan variabel bebas agar penelitian yang dihasilkan lebih signifikan, inovatif dan dapat memperluas pengetahuan mahasiswa mengenai dunia perbankan. 


\section{DAFTAR PUSTAKA}

Mertika Kirana Rimadhani (2010) dengan topik mengenai "Pengaruh LDR, IPR, BOPO, NPL, APB, AU Dan PDN terhadap ROA pada Bank Pemerintah Daerah periode triwulanan mulai tahun 2006 sampai dengan 2009. Skripsi sarjana terbitan STIE Perbanas surabaya.

Kasmir. 2010. Manajemen Perbankan. Jakarta : Raja Grafindo Persada

Laporan Keuangan Bank, www.bi.go.id. "Laporan Keuangan Publikasi Bank”.

Lukman Denda Wijaya. 2009. Manajemen Perbankan. Jakarta : Penerbit Ghalia Indonesia

Winda Ayu Wijayanti (2011) dengan topik mengenai "pengaruh LDR, APB, NPL, FACR, PR, IRR, PDN dan BOPO terhadap ROA pada Bank swasta nasional go public 2006 sampai dengan 2009". Skripsi sarjana terbitan STIE Perbanas surabaya.

Martono. 2010. Bank dan Lembaga Keuangan. Jakarta: Penerbit Ekonosia Kampus Fakultas Ekonomis UII.

Surat Edaran Bank Indonesia No.6/23/DPNP tanggal 31 Mei 2004.

Veithzal Rivai. 2007. Bank and Financial Institution Management. Jakarta : PT. Raja Grafindo Persada.

Nanang Martono. 2010. Metode Penelitian Kuantitatif. Cetakan pertama. PT . Raja Grafindo Persada

Titik presentase distribusi $\mathrm{F}$ dan $\mathrm{t}$, http://junaidichaniago.wordpress.com. 